\title{
As ficções sociológicas de Saltykov- Chtchedrin e de Zinoviev
}

\author{
Johanne Villeneuve
}

RÉSUMÉ: Cet article définit la fiction sociologique et en dégage quatre termes : figure, tragédie, mythologie et histoire. L'auteur dégage les topoï fondamentaux de la fiction de Zinoviev, à savoir l'asservissement volontaire, le souci hypocrite du prochain, la figure du corps et l'oralité. La stratégie logique de cette œuvre mise sur le paradoxe et la satire agençant les isotopies, lesquelles rejoignent celles de Saltykov-Chtédrine puisque l'une et l'autre échappent à la martyrologie et au dispositif du sacrifice.

MOTS-CLÉS: pouvoir, fiction sociologique, parodie, absurde, oralité, dissidence.

Num ensaio consagrado a Tchekhov e escrito no albor do desmoronamento da URSS, o escritor russo Alexandre Zinoviev escrevia: "Considero, de um ponto de vista sociológico, que a contribuição mais significativa de Tchekhov foi a revelação do poder do nada e a análise deste (a 'rotina') como pedra angular de uma sociedade organizada em Estado" ${ }^{1}$. Referindo-se sobretudo aos contos humorísticos de Tchekhov, Zinoviev vê neste último o analista mais completo e mais incisivo dos mecanismos que regem em seu conjunto as relações que a sociedade russa mantém com o poder. A força dessa análise reside em seu caráter humorístico, no que Zinoviev nomeia seu "humor cognitivo" ou sua "sátira sociológica". Haveria algo como uma "essência objetiva" dos "fenômenos da vida" ${ }^{\text {, da qual }}$ só o humor sociológico poderia captar a verdadeira natureza.

Johanne Villeneuve é xxxxxxxxxxxxxxxxxxxxxxxx.

${ }^{1}$ Mon Tchekhov. Ttrad. francesa de Laurent Vogel. Bruxelles: Complexe, 1989, p. 78.

${ }^{2}$ Ibid., p. 153. 
Para Zinoviev, escritor dissidente sob o regime soviético e insubmisso por razões de consciência desde o desmoronamento do regime comunista, o ensaio sobre Tchekhov é um pretexto que serve para estabelecer as fontes de seu próprio empreendimento romanesco: vê em Tchekhov, este por sua vez herdeiro de Gogol e de Saltykov-Chtchedrin, o artesão de uma crítica sociológica, e não política, que transcende as posturas habituais da contestação ou da reivindicação. O filão principal para essa tradição literária russa, desde Gogol até Zinoviev, passando pelo humor de Tchekhov e pela sátira de Saltykov-Chtchedrin no fim do século XIX, não é a questão do poder compreendido sob a forma do aparelho político, mas antes o caráter inseparável do que, na Rússia, une o poder à ficção no seio da ordem social. As manifestações sociológicas do poder estariam todas mais ou menos ligadas ao aspecto ficcional das relações de poder na Rússia. Desde a crítica feita por Gogol à burocracia de São Petersburgo até a sátira de Zinoviev dos funcionários soviéticos, o que anima essa tradição é a descoberta do caráter imanente de um poder que nem por isso permanece menos tirânico e autoritário. É a tese de que "todos os membros comuns da sociedade são efetivamente investidos de uma parcela de poder que exercem sobre os outros." ${ }^{3}$ É antes a proliferação e a diversificação do Terror em múltiplas redes parcelares do que seu enfraquecimento. É o reforço da tirania pela extensão de suas ramificações, sua banalização nos processos de socialização. Contrariamente a outros tipos de poder, quanto mais a tirania se banaliza, mais força ela ganha, até tornar-se o que ordinariamente chamamos "a ambiência geral". É a deriva do poder no círculo de seus paradoxos, o deslizamento do social em sua propensão à entropia, à censura, à interdição e à denegação.

Em um conto escrito por Tchekhov em 1898 e intitulado $O$ homem no estojo ${ }^{4}$, esse deslizamento objetivo da sociedade em direção à sua própria negação, isto é, a destruição de suas forças vivas por meio da delação, da interdição e da auto-censura, é claramente relatada. O homem no estojo opõe-se a qualquer movimento, a qualquer mudança, até mesmo a qualquer modificação que não se conforme estritamente ao que ele crê serem as regras estabelecidas da autoridade. Insignificante funcionário de província, ser desprezável, o homem no estojo tem medo de tudo, a começar pela idéia de ter desejos e de ter, assim, literalmente de sair de si mesmo.

${ }^{3}$ Ibid., p. 88

${ }^{4}$ Em russo, Tchelovek $v$ futliar, título cuja riqueza permanece intraduzível, pois denota uma expressão bem conhecida e usual para designar as "almofadas de couro" e evoca a imagem fortíssima do burocrata literalmente encerrado, lacrado em sua função. 
Comprimido, fechado pelos limites e deveres que lhe confere sua função, obcecado pelos procedimentos administrativos e pelas regras a seguir, ele age policiando tudo, como um homem que a todo momento deve impedir o escândalo, ou seja, qualquer manifestação do acaso e qualquer exteriorização dos desejos. Seu medo da vida é tal que se deixa conduzir à morte sem pestanejar, não podendo lutar por mais tempo contra o ridículo de sua própria existência. Morre por desgaste, para acabar com a vida como se acaba com uma tarefa a cumprir. No final da narrativa, é esposto em seu caixão, do qual o narrador ressalta a exata conformidade com o ideal do morto: o funcionário repousa em seu caixão tal como viveu em seu estojo, para sempre protegido dos acasos da vida. Mas sobretudo - e Zinoviev não cessa de retomar isso ao reler Tchekhov - o sistema que o insignificante funcionário sempre personificava permaneceu funcionando muito tempo após sua morte, porque a lógica do sistema é intrínseca a perpetuação da sociedade:

Essa reflexão sobre o sistema de opressão e a ausência de liberdade na Rússia não era novidade em nossa literatura. [...] O que havia de novo em Tchekhov é que ele sentia o caráter voluntário dessa forma de escravidão [...]. Desde a infância, pude constatar à minha custa que o poder dos próximos é mais assustador que aquele dos órgãos de repressão, pois ele constitui um avassalamento recíproco voluntário entre as pessoas e, ademais, evoca hipocritamente a preocupação com o próximo ${ }^{5}$.

Eis, então, dois topoi para situar a ficção de Zinoviev: o avassalamento voluntário, do qual o poder social não é senão uma denominação ampliada, e a preocupação hipócrita com o próximo à qual se ligará imediatamente o pano de fundo religioso russo, do qual Cristo, figura de compaixão e de abnegação por excelência, é chamado a servir de instância sacrifical.

Nesse livrinho intitulado Meu Tchekhov, Zinoviev aponta então o que o distingue, ele, à maneira de Tchekhov, dos outros dissidentes, isto é, desta inteligentsia "que cai na oposição ao regime [e] não exprime senão seus interesses pessoais" ${ }^{6}$. A análise da sociedade russa a partir dessa pedra angular, que seria constituída pela "revelação do poder do nada" permitiria a Zinoviev, como a Tchekhov, assumir uma relação de real dissidência frente ao Estado. Nesse sentido, ambos correspondem à definição literal do dissi-

\footnotetext{
${ }^{5}$ Mon Tchekhov, p. 82.
}

${ }^{6}$ Ibid., p. 96. 
dente, a saber, "aquele que tem assento ao lado". O escritor não busca assim nem o poder, nem sequer o contrapoder; também não atinge o estatuto de mártir entregue ao sacrifício político. Não busca nem tomar o lugar do poder, nem lançar-se nele ao preço de sua vida. Longe de oferecer sua própria postura de sujeito como pasto, entrincheira-se atrás do ato de leitura ou, para usar os termos de Zinoviev, atrás de sua "concepção lógico-literária consciente... associada a uma crítica científica da sociedade" ${ }^{7}$.É, pois, como sociólogo que o romancista se percebe quando enuncia sua "objetividade romanesca"; mas inversamente, é como romancista que constrói sua sociologia do absurdo, isto é, a partir de uma visão da organização social como "ficção", em que as leis objetivas da sociedade desvendam sua dimensão estética, puramente formal. A beleza intelectual das idéias abstratas, a aventura da discussão social, a dissecção dos raciocínios e das motivações pelos quais se edifica um sistema, a própria coerência do absurdo, eis as diferentes fórmulas de que a ficção sociológica de Zinoviev faz uso. Mais que qualquer outro analista, o romancista está bem colocado para apreender o caráter propriamente ficcional da realidade, os próprios dispositivos da ficção aos quais está profissionalmente habituado.

É no interior deste quiasma entre a ficção e a sociologia, entre a ciência e o romanesco que o dissidente-Zinoviev, não deixando de se ver deslocado, escapa à definição de sua postura em relação ao poder. Ora científico, ora romancista, não cessa de se afundar no círculo vicioso do paradoxo, transformando-o em círculo virtuoso da dissidência. $O$ verdadeiro dissidente é aquele que jamais se encontra onde se espera. Diante da regularidade magnífica das leis da intriga, ele toma o olhar objetivo do cientista; diante da realidade sociológica, baseada evidentemente nessas mesmas leis e nessa mesma regularidade, mas coberta de detalhes improvisados, de contingências e de efeitos discordantes, ele reveste a subjetividade e a soberania do intrigante-romancista. $O$ paradoxo confere a essa obra toda sua intensidade: como efetivamente conciliar a indescritível verborréia que tal arquipélago romanesco ${ }^{8}$ constitui com o rigor metódico da crítica sociológica, cuja perfeita coerência, e mesmo a obsessiva coesão argumentativa, se pode verificar a cada página?

É nesse sentido que a obra de Alexandre Zinoviev é problemática,

${ }^{7}$ Ibid., p. 54.

${ }^{8}$ Além do fato de que a obra de Zinoviev é imensa (vários milhares de páginas escritas com extrema rapidez, convém-lhe ainda publicar um livro cada ano), ela é seguidamente descrita como verbosa, inexaurível, sem começo nem fim. Certos críticos, aliás, criticaram Zinoviev por reescrever sem cessar o mesmo livro, o que ele não nega, na medida em que esta impressão só confirma a coerência da obra, seu caráter inabalável. 
freqüentemente, aliás, descartada dos grandes recenseamentos literários, como uma obra marginal, mas que se recusa a tratar da marginalidade. Sua proposta não será antes "geral”, em vista da vocação sociológica que ela se atribui?

Trata-se, entretanto, de uma obra fundamentalmente ligada à tradição romanesca, particularmente à da sátira. Mas não se pode compreender a pertinência desse trabalho de ficcionalização desconsiderando o projeto sociológico e crítico que nele se encontra confirmado. Ficção e sociologia não só “se entendem bem”, elas constroem juntas o paradoxo fundamental da poética de zinovieviana, elas agenciam, no interior daquilo que as mantém em tensão uma com a outra, as diferentes isotopias sobre as quais o texto se regula. A ficção de zinovieviana é essencialmente sociológica, pois a própria sociedade é um tecido em que se desenham tramas, em que são projetadas ilusões, em que se atam e se desatam relações efêmeras, muitas vezes absurdas. Partindo da espantosa banalidade do cotidiano, de suas anedotas proliferantes, dos desejos birutas e sempre insatisfeitos para os quais a vida em sociedade impele, a ficção sociológica de Zinoviev nos conduz incessantemente da regularidade sombria das coisas à simplicidade formal do paradoxo. Ficção e sociologia, romance e ciência não são os termos de uma justaposição gratuita, mas as figuras de um único quiasma, os topoi de uma única permuta. Paralelamente, a desinência de Zinoviev encontra seu sentido na aceitação de um fenômeno sociológico que ultrapassa em muito a reivindicação política. As leis sociológicas às quais está tão apegado são para ele inegáveis. Ninguém, nem mesmo a bela alma dissidente, pode escapar a essas leis. Toda a obra de Zinoviev deve-se a convicção profunda e tende à demonstração daquilo que o sistema social, sob a forma derivada do Estado, acaba sempre por ganhar, e de que está em sua natureza integrar e regular os fenômenos que parecem inicialmente escapar-lhe; encontrando-se seu equilíbrio sempre restabelecido, a própria dissidência participa, contra a vontade, desse equilíbrio. A tarefa do escritor é então desentocar a soberba regularidade do que se poderia chamar "a verdade do sistema", aquela verdade que se verifica até na "justaposição dos fatos" ${ }^{9}$. Por causa de sua beleza matemática, por causa da violação a que ela submete qualquer probalidade, essa verdade, que não conhece insucesso pois já fez do insucesso o soclo de tudo, seduz tanto quanto assusta. E é graças a essa dupla percepção que a obra de Zinoviev permanece uma obra, ambígua e complexa, apesar de seu invariável credo. É graças a esse instante sedutor, em que toda afirmação se eleva ou se volta para confirmar nova-

${ }^{9}$ Ver particularmente My i Zapad (Nós e o Ocidente).. 
mente a verdade do sistema, em que a tese da obra se vê cada vez fielmente confirmada - a saber, a capacidade do sistema de recuperar a dissidência e, com isso, os leitores críticos que presumivelmente somos - que a obra de Zinoviev não pode ser reduzida a uma simples "obra de tese". Pois aqui a tese não cessa de usar de ardis consigo. Para obter seu efeito diante do poder, o dissidente deve aceitar jogar o jogo e optar livremente por aquilo que se deveria chamar a "coação do deslocamento perpétuo". Afirma alguma coisa, e logo se empenha em deslocar essa afirmação. Com relação à norma institucional, o discurso dissidente não se contenta, pois, em "ter assento ao lado", erige em princípio o que se poderia chamar uma "estratégia do ao lado”. Opera a incessante desestabilização do controle social, fá-lo saltar, sair de seus gonzos; passa o tempo dizendo o contrário do que diz, confirmando-se assim em seu papel de ator irônico da história. A estratégia está no auge quando atinge o nível de depuração do aforismo: "Ninguém é mais implacável para com o fraco que um outro fraco um pouco mais forte que ele. $\mathrm{O}$ fraco é sempre perdedor. É necessário ser muito forte para viver toda uma vida na qualidade de fraco"10 "No próprio Oeste os reacionários mais inveterados lutam pela democracia, pois para eles a democracia é a última possibilidade de lutar contra a democracia" ${ }^{11}$. "O progresso social da sociedade foi antes de mais nada um progresso anti-social”. O enunciado sofístico torna-se a arma do escritor dissidente que não pode senão vencer nesse jogo, visto que ele se reserva todas as possibilidades; sua estratégia consiste em apreender, mimar e predizer a força de regulação do sistema implacável que, a seu juízo, "a lei objetiva da sociedade” constitui: “- Não vejo onde está o problema, disse-me um de meus discípulos. Tudo é vaidade. E então? Por que querer subtrair-se a isso? Pessoalmente, sempre tomei cuidado, e continuo, para agir inversamente: mergulho completamente nessa vaidade e, francamente, nela vivo plenamente." ${ }^{12}$

O herói de Homo Sovieticus descreve bastante bem a estratégia intrigante do dissidente, sua proximidade com o "nada" que Zinoviev invoca à maneira de Tchekhov, e o quiasma entre a objetividade pura e a ficcionalização:

A força do Ocidente não está em sua inteligência e em sua vontade de defesa, mas em sua tolice e em seu desejo de capitular. Por outro

\footnotetext{
${ }^{10}$ In: Zapiski Notchnogo storozha (Notas de um guarda noturno). Lausanne: L’Age d’Homme, 1979 , p. 39

${ }^{11}$ In: Homo Sovieticus. Lausanne: L'Age d'Homme, 1982, p. 45.

${ }^{12}$ Idi na Golgotu (Vai ao Gólgota). Lausanne: Julliard, L’Age d’Homme, 1986, p. 34.
} 
lado, a força da União Soviética deve-se tanto à sua besteira quanto à incapacidade em que se encontra de poder manter com igual vigor sua resolução. Por conseguinte, disse a mim mesmo, no próprio interesse da exatidão científica é preferível que eu escolha as hipóteses contrárias. Mas então... Não há mais necessidade de planos de nenhuma espécie, pois tudo o que ocorre no mundo corresponde perfeitamente a essas hipóteses. Dito de outra maneira, a idiotice dos acontecimentos é a encarnação ideal de planos geniais... [...] O problema não é que a história avança vai na contramão. Acontece justamente que ela avança no sentido correto. $\mathrm{O}$ problema é que o lugar que ocupo nela não é o certo. Num combate entre dois poderosos idiotas não há lugar para um anão inteligente. [...] Minha posição é a de quem chega de outro planeta, indiferente, ou seja, hostil às coisas terrestres. Só tenho, pois, que retornar a meu espaço, ou, se quiserem, a minha miserável concha, e calar-me! $!^{13}$.

Entretanto, essa concha, esse espaço equivalente ao silêncio, ao aniquilamento da palavra, traduz-se aqui, como em toda a obra de Zinoviev, por uma inexaurível verborréia; se existe uma obra que não tem nem começo nem fim e que absolutamente não suporta calar-se, é esta, à qual muitos têm freqüentemente censurado o caráter prolixo e de rascunho. Contrariamente a Tchekhov, cujo cujo laconismo abre o caminho para o nada, é pelo viés da cacofonia, deriva expansiva e excessiva da polifonia, que a sociologia de Zinoviev transforma o absurdo em lei objetiva e puxa o nada para o lado de uma cotidianidade da História.

Num estudo sobre Zinoviev, o crítico Charles Janson questiona-se sobre a dificuldade de cercar a personagem do romancista-sociologista que ele vê ora como um "bobo" provocador e uma criança terrível, ora como um lógico, um "homem de ciência" ${ }^{14}$. Discutindo com o romancista sobre essa ambigüidade, recebeu uma resposta digna do universo ficcional sobre o qual se questiona: "sou um homem soviético típico", terlhe-ia respondido Zinoviev. É esta a própria ambigüidade da ficção sociológica. Pois, o que significa ser "um homem soviético típico" senão pertencer à ficção de Ibansk, esse mundo distópico do qual nos é dito no início de Elevações escancaradas que se trata de um nada, isto é, de uma "localidade que não localiza nada", que "não existe na realidade. E mesmo, se por acaso ela existisse, seria pura fiç̧ão. Em todo caso, se ela é

\footnotetext{
${ }^{13}$ Ibid., p. 169-170.

${ }^{14}$ Ver Charles Janson, “Alexandre Ziniviev: Experiences of a Soviet Methodologist”, p. 23-24.
} 
possível em algum lugar, certamente não é em nós, em Ibansk" ${ }^{15}$.

Bem acima do célebre Ibansk de Zinoviev deve-se colocar aquele lugar imaginário descrito por Saltykov-Chtchedrin no fim dos anos $1860 \mathrm{e}$ batizado "Glupov" na historiografia fictícia e na satírica História de uma cidade $^{16}$. Se Ibansk é um derivado compósito do verbo ebat' ("trepar", "foder" "transar") e de Ivan (o nome mais comum na Rússia e que designa o "russo típico"), Gloupov encontra sua raiz no adjetivo gloupyï ("estúpido", "tolo", "besta") ${ }^{17}$. Em sua crônica, Saltykov inventa os arquivos de uma cidade - lugar a partir do qual pode construir uma história satírica da Rússia. Os glupovianos formam um microcosmo social da Rússia, como Ibansk constitui o laboratório "mítico" e distópico da sociedade soviética, pequeno mundo de uma esfera histórica gigantesca em que a análise e a sátira encontram base. Um século antes de Zinoviev, Saltykov usara de artimanhas com as autoridades e a censura; como ele, descontentara grande parte da inteligentsia russa manobrando ora contra os liberais, ora contra os conservadores. Mas sobretudo, é nele que melhor se reconhece em sua fonte a força quiasmática do dissidente, isto é, o cruzamento entre um discurso de objetivação (pseudo-historiográfico) e um empreendimento ficcional. Saltykov formula uma crítica acerba da hierarquia social e administrativa da Rússia, na qual Zinoviev não terá dificuldade em se inspirar para descortiçar a utopia soviética. Os pontos de convergência entre Elevações escancaradas e História de uma cidade são impressionantes. Os dois empreendimentos, baseados na preeminência da ficção sociológica para a qual a poética é indissociável da pretensão analítica, empregam os mesmos dispositivos ficcionais e têm como ponto de ancoragem comum uma análise crítica do que se nomeia na Rússia o narodovlastie, ou seja, o "poder do povo". Para Zinoviev, a tirania do poder se exerce cotidianamente, em todos os níveis da sociedade, em cada relação humana, até tornar-se uma "lei objetiva". O caráter ficcional de sua obra adquire então sua verdadeira dimensão ética e cognitiva; a ficção dissidente é baseada na natureza fictícia da edificação social, sobre a mentira institucional. Embora, para Saltykov-Chtchedrin, a relação entre o povo e o poder contenha ainda um potencial revolucionário, a própria essência da ordem social - na maioria das vezes descrita

${ }^{15}$ Ziiaiutchchie Vysoty. Lausanne: L’Age d’Homme, 1976, p. 7.

${ }^{16}$ Istotia odnogo godora (1869-1870). M.E. Saltykov-Chtchedrin. Sobraine SotchineniI, t. 8. Moscou: 1969.

${ }^{17}$ Incidentemente, na linguagem infantil, glouposti designa o pênis e os testículos, o que nesse sentido nos aproxima de Ibansk. 
como "desordem" - repousa sobre uma responsabilidade comum, compartilhada entre o povo e a autoridade do Tzar: pouco importa em que extremidade da cadeia social nos encontramos, a total abnegação e o conformismo cego sempre apanha seu homem. Glupov, como Ibansk, não tem outro fundamento senão sua própria ficção. E como em Zinoviev, a força do tirano só é igual à submissão voluntária do povo. Em História de uma cidade a fundação de Glupov é contada como o resultado de uma busca no mínimo absurda. Os glupovianos, oriundos de um povo estranho chamado Malha cabeças, são antes de mais nada "solidários" na autodestruição: "É assim que alternadamente arruinaram suas terras, estupraram suas mulheres e suas filhas, sem entretanto deixarem de se vangloriar de sua bonomia e de sua hospitalidade" 18 . Impacientes em se submeterem o mais rápido possível à uma autoridade que regulasse enfim sua inclinação à desordem, põem-se então em busca de um rei. A história de Glupov começa verdadeiramente por esse gesto de abnegação. Ela se eternizará, ainda segundo a regularidade objetiva do despotismo, de um episódio a outro, de um governador a outro através dos séculos atormentados: “...como vocês foram bastante tolos para se subjugarem a si próprios, a partir de hoje não os chamaremos mais de Malha-cabeças, mas de Glupovianos"19.

Fundamentalmente, como em Zinoviev, a História avança a grandes passos fictícios, não cessando de girar no círculo vicioso do narodvlastie. $\mathrm{O}$ poder do povo, Saltykov o vê ironicamente atuando naquela capacidade de interiorizar a lei social, de confirmá-la, de cercá-la por todos os lados. Essa interiorização é o meio pelo qual a sociedade se edifica ao mesmo tempo em que se autodestrói:

Combatia-se acaloradamente, toda a noite, às cegas e o melhor possível. Houve muitos feridos e mortos. Quando foi dia claro, compreenderam que haviam lutado entre si, na orla do Estrume. Resolveram sepultar os mortos, erguer um monumento no campo de batalha, honrar aquela data... [...] e celebrar-lhe os aniversários com uma festa orgíaca, A Grande Algazarra ${ }^{20}$. Desconhecendo qualquer freio, os glupovianos precipitaram-se com uma espécie de furor para a funesta ladeira que se estendia diante deles ${ }^{21}$. Da manhã à noite, os glupovianos encarniçaram-se em destruir suas próprias moradias ${ }^{22}$.

\footnotetext{
${ }^{18}$ Op.cit., p. 270.

${ }^{19}$ Ibid., p. 275.

${ }^{20}$ Ibid., p. 342.

${ }^{21}$ Ibid., p. 376.

${ }^{22}$ Ibid., p. 411.
} 
Contrariamente a uma certa tradição literária da "martirologia", tradição extremamente forte na Rússia, culminante na virada do século e persistente sob o regime soviético, Zinoviev e Saltykov, como Tchekhov e Gogol em outro registro, recusam o paradigma do "sacrifício trágico". É menos o dispositivo do sacrifício e a obsessão do bode expiatório que fundamentam suas ficções sociológicas do que a pesquisa dos princípios formais da organização social do poder - princípios cujo valor heurístico primeiro consiste em revelar o caráter ficcional e contraditório da história tal como edificada e celebrada pela sociedade em seus mínimos vincos. A ficção sociológica, procedente da sátira e da reflexão analítica, permite descortiçar e deslocar a lógica do sacrifício para descobrir ao mesmo tempo seu fundamento e sua extensão. Esse fundamento não pode ser despachado simplesmente para o lado do religioso, do espiritual, da psicologia ou do político. Não se pode afirmar simplesmente, por exemplo, que a figura secular do "poeta sacrificado" ou a tragédia fundadora do parricídio, tão freqüentemente invocadas como motivos-chave da história da Rússia, são apenas avatares de um pano de fundo em que o espiritual sempre se teria mesclado ao político, em que a mitologia sempre se teria confundido com a história; não se pode simplesmente afirmá-lo, pois no quadro da fiç̧ão sociológica, o religioso e o político só encontram sua verdadeira expressão na lógica da socialidade. À socialidade confere-se uma importância tal que qualquer martirologia ou figura sacrifical não passaria de magros avatares dela. Figura e tragédia, mitologia e história compõem uma só e mesma tela chamada "ficção", cujas malhas oferecem ao olhar sociológico a verdade de um sistema. Essa verdade de um sistema é sem êxtase; não aparece sob a modalidade do milagre, da epifania ou, na expressão de Dostoievski, no "rasgar do véu". Se às vezes ela se faz ouvir com a força da revelação, é porque então usa de ardis com a possibilidade de sua própria enunciação. Como mostram tão claramente as ficções de Saltykov e de Zinoviev, essa verdade sempre parece já esgotada - esgotada por sua própria evidência, pelo caráter repetitivo, forçado, até mesmo banal de sua enunciação.

Essas ficções sociológicas são obras marteladoras, excessivas porque desdobram um imaginário do detalhe, mas deliberadamente pobres por não cessarem de girar em torno do mesmo osso. A parada literária consiste então, para elas, em usar deslocamentos em torno do osso, em retomar incessantemente o mesmo enunciado, mas por meios diferentes, desde perspectivas, vozes, figuras, alegorias cuja variedade confirmaria ainda a inegável verdade da lei social - lei que devora, engole tudo, sorve cada probabilidade do sistema, confirmando assim, e não sem contradição, a perfeição de seu vício.

O que se deixa descobrir nos dois autores é conseqüentemente reduzi- 
do sempre a desgaste, àquilo que já se manifestou muitas e muitas vezes, mas que persiste estupidamente em revestir-se de novidade! Se a ficção sociológica por vezes faz surgir, sob o impulso de um súbito frenesi, criaturas que parecem saídas da utopia ou do fantástico, é porque elas pertencem a algumas profundezas memoriais que há muito entraram em queda e que voltam à superficie em farrapos, beatas e grosseiras. É isso que ocorre com as criaturas descobertas no porão de um dos governadores de Glupov:

[...] criaturas nuas e selvagens que se mordiam, ladravam, se arranhavam e mostravam os dentes quando alguem se aproximava delas. Conduziam-nas ao ar livre e ofereciam-lhes sopa de repolho bem quente. À vista do vapor, elas resfolegaram e manifestaram um receio supersticioso. Após um momento, afoitaram-se e jogaram-se sobre a comida com uma voracidade bestial e renderam a alma imediatamente ${ }^{23}$.

Essa ursificação do glupoviano, essa "primitivização" caricatural cuja saída fatal - o aniquilamento em suma - assemelha-se à autodevoração (morrer por ter comido demais) age no nível microcósmico como caricatura da sociedade inteira, a qual é igualmente movida por uma estúpida avidez, pelo "receio supersticioso" e pelo medo de encontrar-se livre. Essa cena tirada do romance de Saltykov-Chtchedrin prefigura de maneira espantosa a emergência grandiosa de criaturas inesperadas na superfície da realidade ibanesca, quando, ao assistir à inauguração oficial de uma boca de esgoto, os habitantes de Ibansk são testemunhas de um acontecimento espetacular:

O zelador levantou solenemente a placa do esgoto, com um gancho e a ajuda do novo Guarda do PINE. A boca deixou imediatamente escapar um fedor inverossímil que logo envolveu toda Ivanburgo [Ibansk]. Os ivanianos permaneceram mudos de estupor. Os membros da delegação subivaniana puseram-se a sair da boca, um após outro. Seu aspecto chocou os ivanianos de espanto. Estavam preparados para tudo. Durante séculos haviam sido habituados à idéia de que os seres razoáveis das civilizações extraterrestres podiam ter a mais fantástica das aparências. Por exemplo, que podiam assemelhar-se a polvos ou medusas. Ou mesmo... Mas basta dizer que os ivanianos estavam preparados para tudo, menos para isso. Viu-se sair... ivanianos nus, mas com órbitas vazias, cheios de lama, imundos a um ponto inimaginável, insuportavelmente féti-

\footnotetext{
${ }^{23}$ Ibid., p. 401.
} 
dos e cobertos de bichos-de-conta, vermes, piolhos, percevejos e outros parasitas que, ao invés de caçar, eles defendiam amorosamente contra contatos exteriores, possíveis. O chefe da delegação subivaniana [...] saiu por último. Espirou e peidou três vezes, depois pôs-se de quatro. Os membros da delegação subivaniana paralisaram-se à ordem fixa de sentido e entoaram o hino nacional subinvaniano... [...] $\mathrm{O}$ encontro das duas grandes civilizações tinha ocorrido ${ }^{24}$.

Mesmo em sua "radical novidade", as criaturas distópicas de Zinoviev e as criaturas selvagens de Saltykov pertencem ao passado, são tributárias da denegação e do sepultamento do passado, são as testemunhas ainda vivas de sua inevitável putrefação. Elas representam o que cada uma das sociedades silencia em si mesma, a impossível conjunção entre a aspiração grandiosa por um mundo melhor (ora no limite do grotesco, ora no limite do kitsch) e a certeza terrestre de acabar no esquecimento e na putrefação. Vêse aqui ainda a dominação da lei ou da natureza social. A tirania que a sociedade exerce sobre si mesma deve ser pensada nos termos de uma inversão entre a imanência da autoridade (da lei interiorizada no social) e a transcendência tal como formulada radicalmente na relação que o crente mantém com seu Deus (seu pai, seu tzar, sua Verdade eterna). Conservando o caráter de eficácia da imanência e da transcendência do poder, nossos dois autores esforçam-se, pois, para captar-lhe a relação particular. O poder mais despótico, mais vertical, seria o resultado de uma força de abnegação perfeitamente estendida, na horizontal; a verdadeira articulação do poder deveria então supor o duplo dispositivo segundo o qual o "povo" (nível horizontal) confirma sua autoridade sobre a própria opção da tirania negando suas próprias prerrogativas. Esta "afirmação-negativa" só oferece à guisa de oposição real uma posição dissidente que consiste, não em negar por sua vez a afirmação negativa, mas pelo contrário, em ser astucioso com ela calcando-a, mimando-a, adotando-a em suas menores redes significantes. É isso precisamente que Zinoviev compreendeu ao apostar na proliferação das anedotas em que se reiteram sem cessar os comportamentos sociais próprios da afirmação negativa.

Procurando desmontar as metanarrativas do povo russo ou soviético, zombando das grandes veleidades históricas, nossos dois autores logo compreenderam a vantagem das formas simples ou dos gêneros cuja narratividade é difusa: a anedota, o diálogo, o aforismo, no caso de Zinoviev; a fábula de animais, o conto, a crônica e o arquivo, no caso de Saltykov. Esse

${ }^{24}$ Ziiaiutchchie Vysoty, p. 529 
recurso à narratividade "sociológica" permite escapar à tentação autobiográfica ou, ao menos, serve para mascarar os elementos potenciais de uma autovalorização de um escritor em luta contra a censura. A dissidência aqui não passa precisamente pelo "valor das histórias pessoais" dos dissidentes, como foi o caso de Soljenitsyn ou Kundera, segundo Claude Lafarge ${ }^{25}$. Em Saltykov e Zinoviev, as microficções vêm em auxílio à um macrodiscurso historiográfico ou sociológico, e vice-versa. As histórias pessoais são por assim dizer despersonalizadas, enxertadas na linha de frente sociológica, lembradas como exemplos entre tantos outros. É por isso que os dois escritores optam pela utilização de arquétipos: em Saltykov primeiramente, na tradição de Gogol, com a utilização do nome como "máscara” social (os nomes das personagens estão semanticamente carregados e são considerados pertinentes para situar o caráter num horizonte sociológico determinado); depois em Zinoviev, num nível ainda mais elaborado, pela utilização sistemática de um repertório arquetípico de nomes tais como o literato, o intelectual, o deviacionista, o número 1, o neurastênico, o assassino, o colega, o cantor, o acadêmico, etc. e que constitui a retomada paródica do discurso burocrático soviético rico em rótulos ideológicos. Ter-se-á compreendido que "funções" e "desvios" são as duas categorias nas quais repousa o repertório.

O arquétipo, compreendido aqui não mais em sua definição estritamente antropológica e psicológica, mas antes transportado para o registro da ficção sociológica, serve de ponto de ancoragem à crítica dos fundamentos burocráticos das sociedades russa e soviética. Num conto mais tardio, datado de 1886, Saltykov-Chtchedrin atinge um nível de crueza ainda não igualado na crítica do poder. "Kramol'nik" conta o desespero de um homem que se acredita transformado em "cadáver" por não ser mais autorizado a falar e a escrever, um homem ostracizado por seus amigos quanto pela censura, um homem "só no meio do nada" e que, desdobrando-se finalmente, recebe a seguinte constatação: “ [...] acabaram por enterrar você”. $\mathrm{O}$ arquétipo encontra aqui seu sentido na filiação alimentada desde a crítica feita por Gogol da burocracia e da tirania da função social. Saltykov escreve que é necessário matar o homem para pôr fim a essas funções. Desde As almas mortas, de Gogol, a existência na Rússia, como se sabe, só tem realidade se ela for recenseada em algum lugar numa lista oficial, menos-

\footnotetext{
${ }^{25}$ La valeur litteraire: figuration littéraire et usages sociaux des fictions. Paris: Fayard, 1983: "Os dissidentes dos países do leste têm um lugar particular na esfera ocidental: a repressão que tingiu Soljenitsyn ou Kundera prova primeiramente aos intelectuais que seus discursos têm uma importância, e a importância desses escritores começa pelo valor de sua história pessoal" (p. 323).
} 
prezando a vida e a morte. Contra o poder da letra, Saltykov e Zinoviev vão opor uma escritura mimética dos textos de lei e de ciência, mas nutrida por uma oralidade muito forte e cujo alcance ultrapassa em muito o que a crítica entende ordinariamente pelo conceito de oralidade.

Assim, se o arquétipo permite às duas poéticas assentar seu valor mimético e constituir-se em filiação com a tradição gogoliana, a oralidade torna-se a principal rede pela qual a tese proposta por cada uma de suas ficções usa de ardis consigo mesma. Nesses dois autores, as categorias usuais que são o monologismo, o dialogismo e a polifonia perdem parte de sua pertinência. Particularmente no caso de Zinoviev, pois, para ter valor de dissidência, a autorialidade que subjaz ao texto deve ser ao mesmo tempo única, só, marginalizada e difusa, isto é, enroscada simultaneamente nos silêncios e nos discursos, nos entrançados e nas entre-palavras do social. Mas, contrariamente ao que a teoria bakhtiniana da linguagem e, a fortiori, a da polifonia estilística permitiriam sustentar, a pluralidade dos discursos na ficção sociológica enriquece realmente uma tese; a voz do autor se levanta realmente acima das outras das quais ela se serve para assentar sua demonstração. Em Zinoviev, estamos diante de uma sociologia que coleciona e explora a diversidade dos discursos, mas que continua sendo guiada por um princípio teórico forte. À primeira vista, a simples utilização dos arquétipos bastaria para colocar a ficção sociológica entre as obras monológicas. Várias formas discursivas de valor sociológico (o que nos reconduz sempre ao campo bakhtiniano) são colocadas à disposição desse laboratório, dessa experimentação teórica, mas também de uma visão fundamentalmente empírica em que a acumulação de provas supera a observação objetiva: anedotas contadas, verborréia e rumores públicos, conversas de bares, micro-ensaios, análises políticas, poemas, canções, grafitos, propaganda, aforismos, preces, confissões, estatísticas, polêmicas, diálogos, jargões científico e sexual, gíria burocrática, tautologias, paradoxos, demonstrações lógicas, etc. Tudo está aí para construir, edificar, afinar o que já se eleva como uma verdade imutável: o próprio edifício do poder em sua verdade sociológica.

Meu objetivo não é readaptar a teoria bakhtiniana em função da ficção sociológica. Trata-se antes de contorná-la, a fim de evidenciar um elemento muito mais importante desse impacto da oralidade na escritura de Zinoviev. Na verdade, existe um sujeito teórico que age como "garatujador absoluto" da fição sociológica; mas esse sujeito pseudo-científico, manipulando continuamente com as leis objetivas da sociedade da qual procura demostrar as mínimas penetrações, nunca coincide consigo mesmo; sua própria tese apanha-o sempre, incluindo-o no círculo vicioso segundo o 
qual é impossível ao homem sociológico sair da lei sociológica. Cada vez que nosso espírito objetivo, científico, aponta para a verdade sociológica, é para deixá-la mostrar com toda a ingenuidade que ele próprio não é outra coisa senão o produto dos discursos frívolos e das utopias derrubadas. Isso confere, portanto, ao sujeito dissidente, em complemento de sua inabalável fé na lógica objetiva da vida, uma temível modéstia - fruto no mínimo paradoxal da ficção sociológica. É na qualidade de "nada" com respeito aos outros que o romancista-sociólogo tem toda autoridade na matéria, é por isso que aceita esse estatuto de "nada", não como postura sacrifical, mas, pelo contrário, como elo indelével que prova sua solidariedade com as desilusões sociais. Sua inserção entre os discursos, sua capacidade de visitar todos os lugares em que acontecem as conversas, em que se dizem as coisas, sua aptidão para reconhecer lá sua própria ausência (deixe-me mostrar-lhe que estamos sempre ao lado da verdade) e ao mesmo tempo sua própria presença (deixe-me mostrar-lhe que a verdade sempre já está aî) confirma uma autoridade no texto da qual não se pode dizer que é simplesmente monológica, nem mesmo não-polifônica.

A solidariedade manifesta desta instância de autoridade com as desilusões da sociedade, esta implantação da palavra autoral no próprio seio da comunidade dos tagarelas tão freqüentemente atuantes em Zinoviev traz uma inovação importante no domínio da teoria da oralidade: efetivamente, o corpo sacrificado do poeta - motivo muito caro à literatura russa -, é substituido aqui pela aceitação absolutamente etílica da autonegação. Beber para romper o silêncio e perpetuá-lo ao mesmo tempo; beber para selar sua vinculação à sociedade dos bêbados, apaixonados por verdade e por vertigem; beber para desaparecer e saber-se no mundo; gesto em que se liga ainda o pano de fundo do niilismo russo ao humor soviético. A postura etílica, se é que ela existe, corresponde ao desejo de mostrar-se com os outros, solidário na adversidade e na polêmica, capaz de uma cólera da qual sempre se poderá dizer "que não era nada", nada além de um excesso de álcool. Assim, o dissidente adorna-se com uma temível humildade! O bêbado jamais é pego de surpresa porque sempre se encontra sozinho no meio dos outros, mas sempre habitado na solidão. Essa constatação vale contanto que se leve em consideração o que representa a bebedeira na Rússia em sua mais pura tradição do companheirismo: “a [...] factor seems important here: the social surroundings in which drinking occured. The rituals, customs, and traditional culture of drinking in Russia assumed that one drank in company. As a temperance advocate remarked in 1894, the simple man of the people (prostoliudin) thought 'vodka was not vodka, if 
he did not drink it in company of others" "26. Eis por que o etilismo adquire desde logo a dimensão de uma disposição sociológica em Zinoviev. A humildade do bêbado, sua capacidade de denegação e seu recurso freqüente à autonegação, num contexto sempre socializado mas que abre ao mesmo tempo a porta à dissidência, representam a única chance de exercer a palavra - em seus duplos sentidos e seus não-sensos. A lógica sacrifical vê-se desnaturada, senão impossível nesse contexto, pois o corpo do bêbado já está lançado, abandonado, corrompido, inapto ao cumprimento de uma perda de valor. A lógica zinovieviana é de invalidação: cada enunciado comum, tirado das conversas usuais e quotidianas como dos grandes projetos históricos, é reconduzido a seu alcance sofístico, invalidado. É esse processo de invalidação constante que por sua vez valida o sistema, prova sua coerência. Nenhum sacrifício aqui, mas antes, a simples descarga dos discursos sociais.

De certa maneira, o motivo do poeta sacrificado explica-se na Rússia pelo fato de que o próprio gesto de escrever comporta um aspecto sagrado e um alcance ético incontestável. Jamais se lembrará bastante que, sendo na Rússia o direito de escrever um direto público não consentido de vez, ele constitui um privilégio outorgado pelo Estado ${ }^{27}$. Somente podia ser escrito o que merecia a transmissão. Toda escritura levada no tom da autoreflexividade, no registro dos assuntos pessoais, era considerada culpada por ataque à ética pois desafiava essa fronteira entre o público e o privado. Por meio das anedotas e dos diálogos etílicos, Zinoviev menospreza essa tradição e volta-a contra si mesma: o bêbado, tagarela inexaurível, assume uma palavra e, no caso que nos interessa, uma escritura plenamente sociais, públicas mas sem pudor e sem vergonha. É exatamente o inverso do homem santo: só e público como esse último, ele figura todavia aquela propensão que a palavra pública tem de produzir o vazio em torno de si, de ver o discurso recair sobre si mesmo pela força da inércia. Nisso, longe de transgredir a regra da autorização pública dos discursos, a palavra do bêbado que ficou sozinho consigo mesmo continua a carregar em sua própria e dolorosa solidão a palavra pública. É a solidão de quem tudo viu, tudo ouviu, tudo memorizou e tudo refletiu mas a quem os curiosos, ocupados com seu afazeres, não vêem. O bêbado torna-se então o único corpo

${ }^{26}$ Patricia Herlihy. "Joy of the Rus': rites and rituals of russian drinking". The russian review, v. 50, n. 2, Ohio State University Press, 1991, p. 146.

${ }^{27}$ Ver a esse respeito o artigo muito eloqüente de Donald Fanger "Conflicting imperatives in the model of the russian writer: the case of Tertz/Siniavsky". In: Literature and history: theoretical problems and russian case studies.......... Stanford University Press, 1986. 
social apto a sustentar ao mesmo tempo o silêncio pesado da sociedade e sua histeria tagarela; torna-se o único a conter e a misturar em sua boca, em sua solidão, em sua negação, discursos públicos e discursos privados. E essa tarefa assumida pelo bêbado lembra, em um pisca-pisca grotesco, que o próprio Estado confunde quando quer a esfera privada e a esfera pública, intrometendo-se nos papéis pessoais e nas confidências de ante-sala ${ }^{28}$.

Se o etilismo é o modo pelo qual se constrói em Zinoviev o corpo social, é à obsessão da devoração e aos excessos de comida que Saltykov-Chtchedrin deve a edificação de um corpo histórico, grandioso e societal. Em um conto intitulado Dois generais e um mujique, essa obsessão pela comida traduz-se pelo surgimento repentino, numa ilha deserta, da "necessidade de trabalhar para subsistir". Verifica-se bastante depressa que o próprio edifício do poder, com sua estrutura hierárquica, depende inteiramente da cadeia do trabalho, modelada sobre a cadeia alimentar: o mujique deve trazer para seus senhores a comida que lhes permitirá manter sua autoridade sobre ele. O poder é, portanto, inversamente proporcional à capacidade de encontrar ou de produzir comida. Cada pólo da hierarquia permanece cego ao enunciado que lhe concerne nessa lógica: o mujique não tira as conclusões quanto ao poder de esfomear os dois generais; os generais não compreendem que o mujique detém esse poder. Para cada qual, a hierarquia social do poder confunde-se com a ordem natural das coisas.

É na História de ume cidade que a obsessão alimentar e o excesso de comida, sempre ligados ao próprio poder excessivo, compensam da melhor maneira pelas figuras sacrificais típicas da tradição literária russa. A História de uma cidade conta essencialmente a perda sucessiva dos governadores da cidade, a nomeação de cada um, mas sobretudo o fim de cada um. Aqui a história devora seus governadores com uma desenvoltura surpreendente. No capítulo quatro, o autor apresenta uma lista sucinta dos governadores em que figura, para cada um, um curtíssimo resumo. Cada um é expedido com furor para os arquivos. Diz ali que eles morreram, ora de tédio, ora muito violentamente, ora por terem devorado demais. Saltykov-Chtchedrin substitui os motivos seculares do poeta sacrifical e do regicídio por corpos desmembrados, expedidos, transformados literalmente em pasto (em carne em pasta). Sinal importante: são as cabeças dos go-

\footnotetext{
${ }^{28}$ Em relação a isso, lembremos que a delação é um assunto há muito estimulado na Rússia e sob o regime soviético, como a melhor intromissão do Estado nos negócios privados "que lhe dizem respeito!" Nesse sentido, o interrogatório constitui um verdadeiro "gênero" em que se confirma totalmente esta confusão assumida por todos - tanto pela polícia secreta quanto pelo suspeito - entre o privado e o público. O Estado tem, portanto, a total exclusividade dos meios pelos quais se vê rompida a fronteira entre as duas esferas.
} 
vernadores que chamam particularmente a atenção do "historiador", sem dúvida por constituírem as verdadeiras figuras alegóricas do poder; assim ele vai ressaltar até o delírio, até torná-las irreconhecíveis, as obsessões do assassinato sacrifical. $\mathrm{O}$ assassinato, as piores sevícias e o sacrifício tomam feitio de carnaval e de repasto, uma expressão perfeitamente hiperbólica em que o desmembramento é multidão:

"Antes de ser pendurado, cortou-se a garganta com um pepino" (p. 36); "Biron, duque de Curlândia, fê-lo vir da Itália [trata-se do novo governador] por sua habilidade em preparar macarronadas... Acusado de traição em 1734 , foi açoitado, teve as narinas arrancadas e foi exilado [...]" (p. 38) "[...] quando atravessava uma floresta, foi despedaçado por cachorros" (p. 39); "Foi encontrado morto em sua cama em 1756. Os percevejos o tinham devorado." (P.40); “Media sete pés e quatro polegadas [...] Partiu-se em dois por ocasião de uma tempestade que causou estragos em 1761" (p. 40); "[...] Conselheiro de Estado e Cavaleiro [...] introduziu em Glupov a fabricação da cerveja, do hidromel e o uso da mostarda e do lourocomum [...]" (p.40); "Morreu de indigestão em 1779" (p. 41), etc.

Em um dos episódios, a cabeça do governador está vazia e amovível. Poder e autoridade se revelam então sob uma luz surpreendente: ambos revelam na realidade a mecânica de uma caixa vazia, verdadeira caixa de música. Esse episódio encontra mais adiante uma ressonância ainda mais impressionante, quando um marechal é obsecado pelo cheiro de túbera de seu governador:

O marechal por muito tempo combatera este pensamento, em que via o delírio de uma imaginação culinária demasiado ardente. Mas, a cada entrevista com o governador, suas suspeitas faziam-se mais insistentes. Por fim encolerizou-se e declarou suas dúvidas ao secretário da Caixa de Previdência da nobreza... Ele cheira a... diz a seu confidente estupefato, ele cheira a salsicharia! ${ }^{29}$

Um dia de carnaval, o marechal vê confirmarem-se suas dúvidas no momento preciso em que, inclinado sobre a cabeça de seu superior para melhor aspirar "sua essência de porquinho", ouve este dizer entre dentes: "Canalha! Ele compreendeu!" A seqüência é previsível. Após uma dolorosa discrição, o marechal acaba suplicando a seu governador que o deixe expe-

${ }^{29}$ Op.cit., p. 177. 
rimentar um pequeno pedaço. Diante de tantas falsas solicitudes e obsequiedades perversas, o governador começa a ceder:

Tentou, no entanto, fracamente resistir, ao longo de um breve combate singular. Mas o marechal, fora de si, não sabia mais o que estava fazendo. Seus olhos cintilavam, sua barriga o torturava deliciosamente, ele ofegava, gemia, chamava o governador "meu biju", "minha boneca"... cheirava-o, lambia-o... Acabou por atirar-se sobre ele com uma ferocidade sem nome, com a faca na mão, e por cortar da cabeça cobiçada uma fatia que logo engoliu. Depois voltou à carga e a devorou até a última migalha....

A obsequiosidade, a busca ávida do poder, a inveja, a bajulação são temas recorrentes da literatura russa, pois a organização social de onde transpira em cada escalão a hierarquia severa do poder na Rússia, em cada uma de suas ramificações, apoia-se justamente em tais mecanismos relacionais. A ficção sociológica de Saltykov toma esses mecanismos ao pé da letra e traduz precisamente sua natureza excessiva. Ao poder da devorarão estática, o escritor não opõe nada, ele hiperboliza, caricatura e leva o sistema a se autoconfirmar. Fundamentalmente sua posição crítica repousa no exercício de uma lógica implacável a qual nem ele próprio consegue escapar: a lógica de um sistema, a de uma sociologia cuja "lei objetiva" é tão visível e desmontável quanto uma caixa de música. É, pois, o desempenho do sistema que a ficção sociológica contesta, a partir da idéia de que o caráter ficcional já está na organização social do poder, inscrita nas paradas do naradvlastie. Se o povo reclama uma certa democratização do poder, deve então levar em conta essa lógica, aprender a desmontar-lhe os mecanismos, a reconhecer-lhe o caráter vicioso.

As escrituras dissidentes das quais acabamos de falar, apesar de colocarem o problema da marginalização, não são escrituras da marginalização, mas antes leituras da relação instituída entre a margem, que presumivelmente resiste à tirania, e esta tirania cuja eficiência repousa essencialmente na capacidade de recuperar no seio de seu sistema todas as incoerências que a vida social impõe. Usando a figura do corpo, quer em sua relação etílica com o mundo, quer pelo exagero dos desmembramentos e da devorarão carnavalescos, Saltykov-Chtchedrin e Zinoviev desdobram a imagem de um "corpo social". Esse corpo edifica-se na medida da sociedade cuja lei objetiva ele somatisa. Por que o corpo? Por que o corpo social atrofiado na boca do bêbado tagarela? Por que o corpo social cuja cabeça

\footnotetext{
${ }^{30}$ Ibid., p. 179.
} 
simbólica corre o risco da devoração ou da degolação? Em ambos os autores, a figuração pelo corpo ficcional lembra a própria ficcionalidade da organização do poder, seu valor altamente simbólico. Mas sobretudo, tratase de colocar uma vez mais a equação entre as esferas do privado e as do público. Trata-se também de não fazer mais repousar a paz social no sacrifício do poeta, do mensageiro, desinvestindo, desmobilizando ou exagerando o mecanismo sacrifical. Além disso, o corpo permite expor de maneira evidente a naturalidade da organização social do poder, esse emaranhado das "impulsões naturais" de cada um e da racionalidade estatal.

Explorando a historiografia carnavalesca ou a anedota etílica, as escrituras de Saltykov-Chtchedrin e de Zinoviev edificaram por sua vez de modo paródico ficções sociológicas em que se opera uma desfiguração da lógica sacrifical. Pela metaficção, ultrapassaram o estágio da culpabilidade ou da vitimização do poeta para estender o problema da autodestruição e da invalidação à lógica de uma sociedade inteira - sociedade que, aliás, jamais soube onde classificar exatamente esses dois escritores. À figura sacrificada do poeta ou do profeta mártir, tal como encenada, por exemplo, em Dostoievski, Biely, Blok e, mais próximo de nós, Tarkovski, a ficção sociológica substitui a desfiguração do tagarela etílico ou a de um corpo de poder infinitamente restituível. Pois é esta a conclusão à qual levam os empreendimentos críticos de Zinoviev e de Saltykov: a lógica do poder, subjacente às da subordinação e da dominação, é intrínseca ao social, carrega em si a eficácia do social, seu caráter regenerador, a força de sua amplidão. O sistema é por definição autodevorante: e é esse caráter de autodevoração, de neantização regulada, que lhe permite justamente bastar-se a si mesmo, nutrir-se, repetir-se e superar sua inércia. Zinoviev terá repetido freqüentemente: o sistema não encontra melhor alimento que sua própria inércia. Nisso ele é modelado pelo bêbado. Seu pão é o produto de seus recomeços infinitos: "Ao longo deste período, toda a imundície do modo de vida soviético veio às claras, a fim de que cada um se penetrasse de seu espetáculo, e se fez de meio natural e de pão de cada dia para qualquer pessoa sã e normalmente constituída" ${ }^{31}$.

Traduzido por Cássia Ducati e Ignacio Antonio Neis

${ }^{31}$ Svetloe Buduchtchee (O futuro radioso). Lausanne: L’Age d’Homme, 1978, p. 52. 